\title{
An Advanced Method to Fuzzy Logic Based on Hybrid Renewable Power Optimization, Real Time Application
}

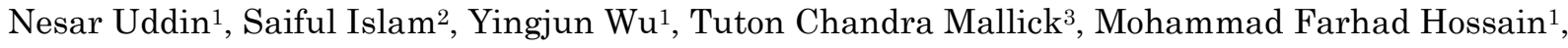 \\ Ishaque Mozumder ${ }^{2}, \mathrm{Al} \mathrm{Mamun}{ }^{4}$ \\ 1 Hohai University, Nanjing, China \\ ${ }^{2}$ Chittagong University of Engineering and Technology (CUET), Chattogram 4349, Bangladesh \\ ${ }^{3}$ Premier University, Chittagong, Bangladesh \\ ${ }^{4}$ University of Bremen, Germany
}

(Received 21 March 2021; revised manuscript received 15 June 2021; published online 25 June 2021)

\begin{abstract}
This research article presents the optimal production and proper management of energy consisting of various renewable energy sources and battery cooperatives for the Rohingya community of Teknaf in Cox's Bazar. By generating 210 units of electricity per day on a small scale; people can fulfill their load demand using a combination of solar, wind, and Biomass power for a few families. At first, an optimization software HOMER has been used for optimizing the amount of renewable power and battery needed based on different input parameters for an effective energy management optimization. Then FLC is used for a proper energy management optimization system within which the given fuzzy rule can perform nonlinear functions used with its own intelligence. The fuzzy rules are designed not only to work at any time of the day but also to use the battery after the load demand is met when renewable energy sources are not plentiful. Optimum and management results have been provided that are much effective in the conventional method. In the meantime, rule view show that there is a proper correlation between energy production and battery charge-discharge, dummy load, and load demand, which in turn reduces unnecessary wastage of energy.
\end{abstract}

Keywords: Hybrid renewable power optimization, Fuzzy system, Energy allocation optimization, Energy management optimization.

DOI: 10.21272/jnep.13(3).03024

PACS numbers: 07.05.Mh, 87.55.de, 88.05.Ec

\section{INTRODUCTION}

Recently, Rohingyas who hai been come from Myanmar to Bangladesh have been living in a hilly area near the beach in Cox's Bazar. The government of Bangladesh and the world organization have been giving them huge grants. Even though they are facing various problems there. One of the major problems is electricity that yet not reach there, which makes their lives much more difficult.

Modern world is moving renewable energy because a large part of this electricity comes from nonrenewable energy [1]. Simultaneously, this nonrenewable energy emits various harmful gases that cause serious damage to the environment. In the meantime, almost all the developed countries in this world like the USA, China, Canada, Germany, Japan, Russia, India that emits more carbon dioxide are trying to shift from nonrenewable energy to renewable energy [2]. Now, China has the world's largest solar and wind power projects. India is setting up a $648 \mathrm{MW}$ solar power plant. The most used solar panels in the world are in Germany [3].

The world's biggest problem is global warming due to climate change, which the United Nations and world environmentalists are encouraging the use of renewable energy to reduce carbon emissions [4]. So, all the scientists in the world are paying more attention to the new technology of renewable energy so that the environment is right for us to survive. And one of the biggest potential sources of electricity for this renewable energy is solar energy, which is suitable for most countries in this world [5]. With the advancement of technology, now it is possible to increase solar energy efficiency by converting it into electricity.

The results were presented at the International Conference on Innovative Research in Renewable Energy Technologies (IRRET-2021)
Again, a large part of the electricity is wasted by the rest of this world due to not controlling the energy properly which is about 8 to 9 percent [6]. Therefore, we are using FLC for the proper use and proper management optimization of energy for reducing energy wastage in the distribution site.

\section{METHODOLOGY}

This research paper has two parts. The first one is energy allocation optimization, and the second one is energy management optimization. Although energy allocation optimization is for the Rohingya community, energy management optimization is universally applicable.

\subsection{Energy Allocation Optimization}

\subsubsection{Study Area and Resources Assessment}

For this research work, the area that is 21.42 North latitude and 91.98 East longitude in Bangladesh have been selected to solve the power problem of Rohingyas in the Rohingya camp of Teknaf in Cox's Bazar [7]. It is a hilly area beside the beach of Cox's Bazar. As a result, the area is very suitable for solar power, wind power, and biomass power. We are writing a research paper for a section of the Rohingya population where it is possible to generate about 210 units of electricity for about 150 households a day. Daily average solar radiation in the area is $4.5 \mathrm{kWh} / \mathrm{m}^{2} /$ day, and the regular wind velocity is $3.479 \mathrm{~m} / \mathrm{s}$. In the city of Cox's Bazar found an average of about 330 tons of solid waste per day which pollutes the city. We can use a part of this waste as biomass energy. 


\subsubsection{System Description}

The entire system which is taken is consists of solar panels, wind turbines, and biomass as renewable energy sources that are the inputs of FLC. Two more inputs are the battery's SOC and load demand. The output is connected with load with renewable energy production, battery charge-discharge-not use, and dummy load. That is shown in Fig. 1. Batteries have been used to solve power problems when renewable energy is not always available. AC/DC converters have been used to connect with AC loads and batteries.

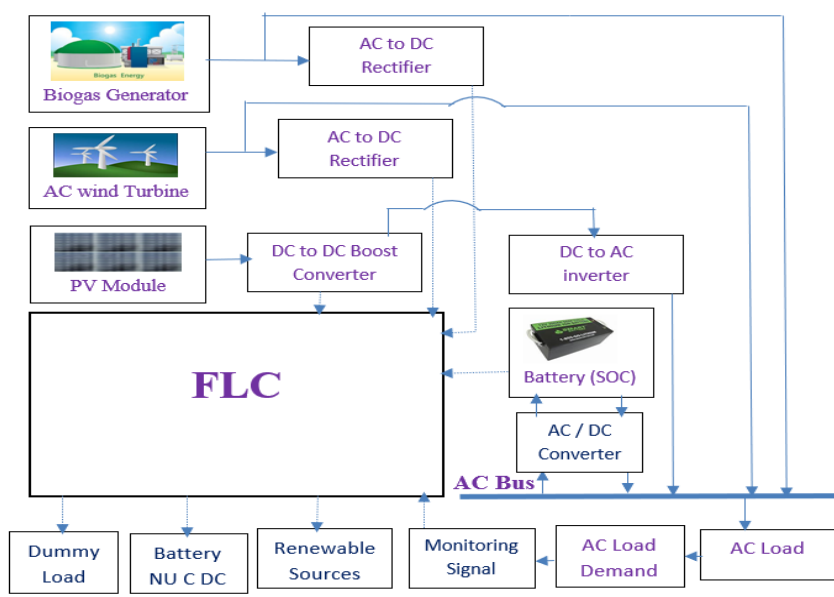

Fig. 1 - Complete block-diagram

\subsubsection{PV Array}

Solar power is the process of converting light rays of different frequencies from the sun, which is the center of our solar system, into electricity through semiconductor devices. The electricity generated from solar panels is calculated with the following equation [8]:

$$
P_{\text {solar }}(t)=\eta_{\text {solar }} \cdot A_{\text {solar }} \cdot S(t),
$$

where $\eta_{\text {solar }}$ is the efficiency of PV arrangements, $A_{\text {solar }}$ is the whole area of solar panel arrangement in $\mathrm{m}^{2}, S(t)$ is the solar illumination $\mathrm{kW}$ per $\mathrm{m}^{2}$. Regular monthly PV illumination for a year has been presented in Fig. 2.

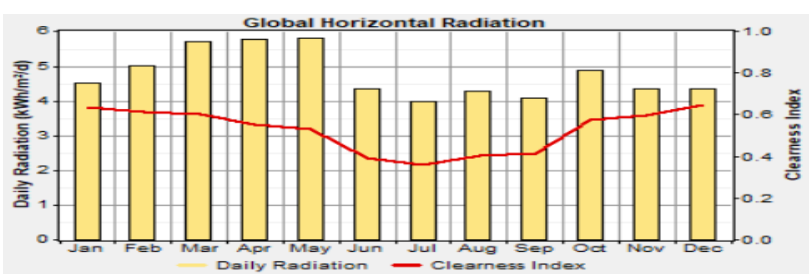

Fig. 2 - Average monthly solar radiation

\subsubsection{Wind Model}

The method of generating electricity by moving the wind speed through the turbine due to variations in wind flow is called wind power. The power received from the wind is calculated by the equation [9]:

$$
P_{t}=C_{p a} \frac{1}{2} \rho_{a} A v^{3},
$$

where $\rho_{a}$ is the wind density, $v$ is the wind speed, $A$ is the area of the turbine rotor, $C_{p a}$ is the coefficient of power. Fig. 3 shows the average wind speed data.

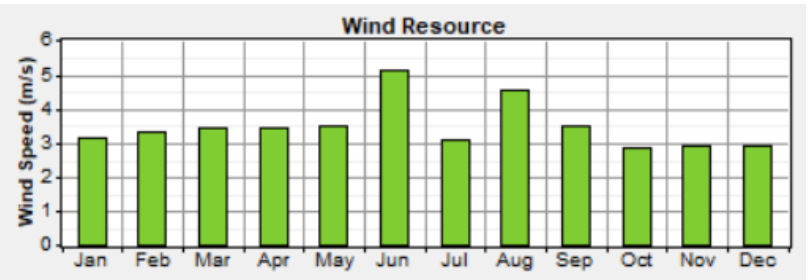

Fig. 3 - Average monthly wind speed

\subsubsection{Biogas Generator Model}

Biogas is a solid compound of various types of gas which come from cow, goat, chicken dung, abandoned leaves in forest or hilly areas, municipal garbage, abandoned parts after cooking produces through the photosynthesis method. Photosynthesis can be described by flowing chemical reaction [10]:

$$
\mathrm{C}_{6} \mathrm{H}_{12} \mathrm{O}_{6}+6 \mathrm{O}_{2} \rightarrow 6 \mathrm{CO}_{2}+6 \mathrm{H}_{2} \mathrm{O}+19 \mathrm{MJ} / \mathrm{m}^{3},
$$

where $\mathrm{C}_{6} \mathrm{H}_{12} \mathrm{O}_{6}$ represents the biomass resource. Fig. 4 represents the average biomass data.

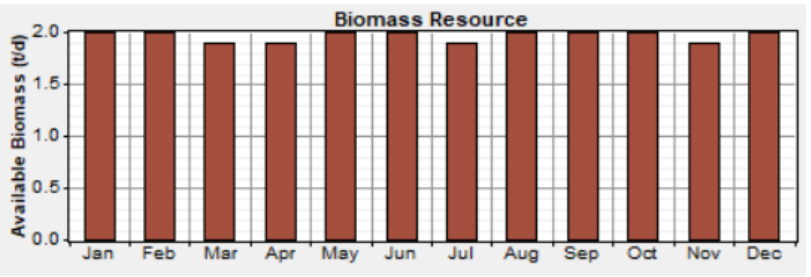

Fig. 4 - Monthly regular biomass biodegradation in ton

\subsubsection{Load Profiles}

Load demand is targeted for a total of 210 units for hot and cold seasons. An ordinary load difference is $10 \%$, and the time-to-time load difference is $15 \%$ has been deliberated. Fig. 5 and Fig. 6 represent daily load profile for summer and winter separately.

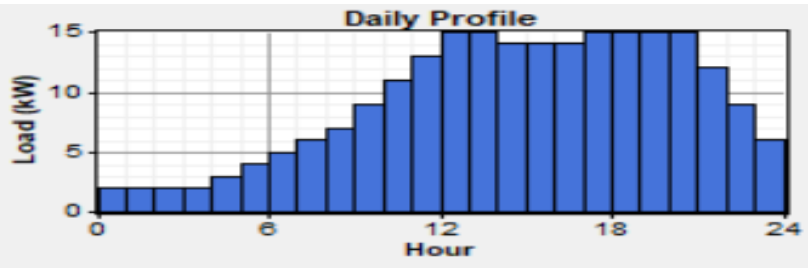

Fig. 5 - Everyday load outline for March-November in kW

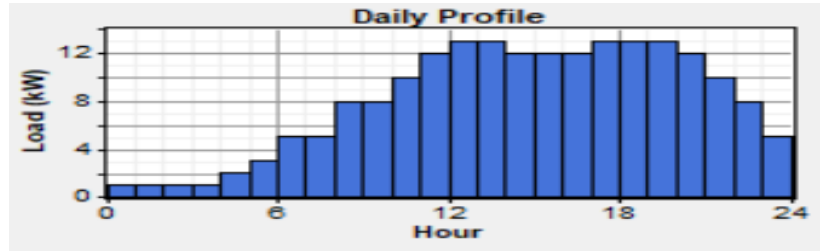

Fig. 6 - Regular load outline for December-February in $\mathrm{kW}$

The structure is designed for 210 units, 150 families where there will be $5 / 6$ people in each family, and they 
will be able to use $220 \mathrm{~V}, 50 \mathrm{~Hz}$, lamp, fan, TV, charger. By calculating, electric energy is considered $1.508 \mathrm{kWh}$ and $0.738 \mathrm{kWh}$ per day separately for summer and winter seasons.

\subsubsection{Optimization Model Using HOMER}

Homer is an optimizing software where various input parameters such as solar radiation, wind speed, biomass data, capital cost, replacement cost, maintenance cost, load demand are given. The homer gives different outputs based on the input such as how much renewable component of energy is required from any renewable sources for energy management, batteries, converters, overall cost. Fig. 7 is the optimizing structure of homer.

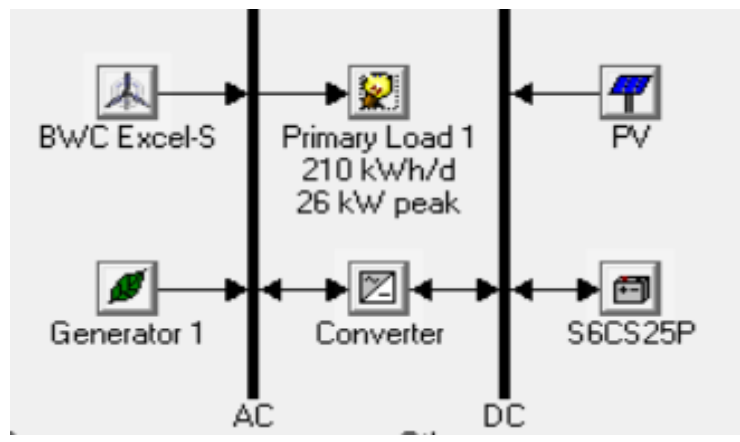

Fig. 7 - Proposed hybrid energy generation system

\subsection{Energy Management Optimization}

For optimizing system, fuzzy logic is used to manage renewable energy by which it is possible to reduce the waste of electricity. FLC involves five inputs and three outputs. The inputs are solar panel, wind turbine, biomass source, battery's SOC, and load demand, which are shown in Figs. 8-12. The outputs are load switching with renewable power, battery switching, dummy load switching. The triangular membership function has been selected as the membership function for each input/output because they are more efficient than other membership functions. Three membership functions have been selected for solar energy, namely, no, medium, high. Three membership functions have been selected for wind power, the battery's SOC, and load demand, namely, low, medium, high. Three membership functions have been selected for biomass power, i.e. Not Available, Medium, High. Four membership functions have been selected for the first output of FLC, and they are wind power, solar + wind power, wind + biomass power, and solar + wind + biomass power. The 2nd output of FLC has three membership functions those are battery non-use ( $\mathrm{S} 1)$, battery charge (S2), and battery discharge (S3). In the 3rd output of FLC, two membership functions are selected, the first to avoid the connection of renewable energy with the dummy load (S1) and the next to make the connection (S2).

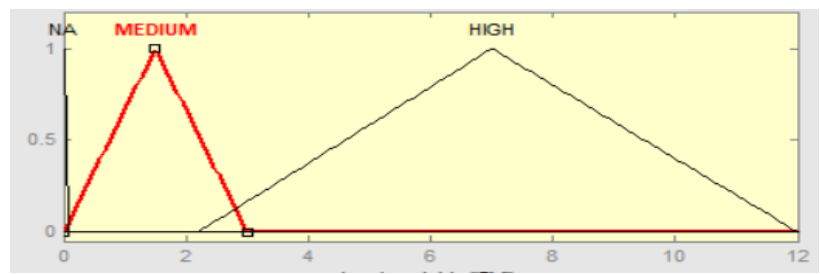

Fig. 8 - Membership function of PV array in $\mathrm{kW}$

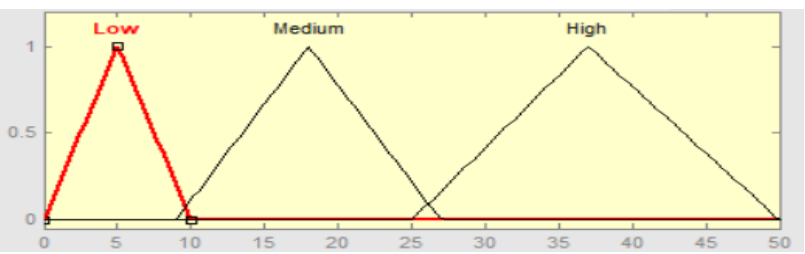

Fig. 9 - Membership function of wind power energy in $\mathrm{kW}$

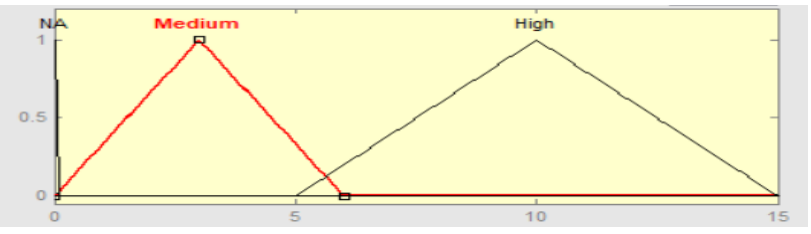

Fig. 10 - Membership function of biogas generator (BG) in kW

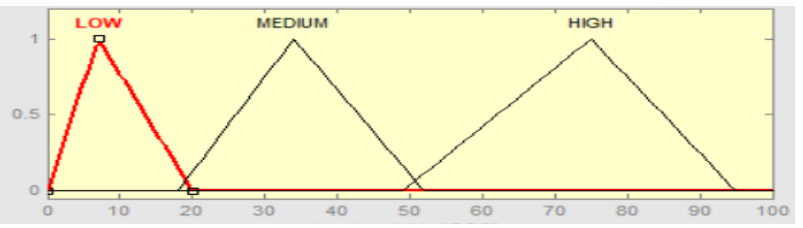

Fig. 11 - Membership function of SOC in percent \%

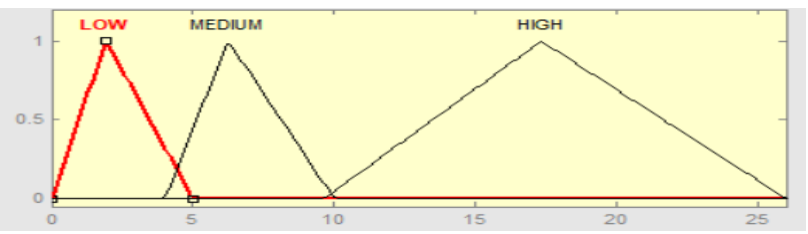

Fig. 12 - Membership function of load request in $\mathrm{kW}$

The FLC works based on IF-THEN rules that are given from human thinking. IF acts as the input and THEN acts as the output. Here, 68 rules have been developed for reducing the waste of energy and appropriate interval shown in Table 1 . Fuzzy rules are made in such a way that can work in any situation. In the biomass generator, several rules have been made for definitive time so that the highest load demand can deal with. Besides, the fuzzy rules are created in such a way that the extra power can provide a dummy load after charging the battery. Here is the rule for the battery has been designed in such a way so that the battery charge below $20 \%$ cannot give electricity to the load and automatically will be closed when $95 \%$ to be deducted. As a result, the durability of the battery will increase. 
Table 1 - Fuzzy rules

\begin{tabular}{|c|c|c|c|c|c|c|c|c|c|}
\hline \multirow[b]{2}{*}{ Time } & \multirow[b]{2}{*}{ No. } & \multicolumn{5}{|c|}{ IF } & \multicolumn{3}{|c|}{ THEN } \\
\hline & & PV & Wind & Biogas & SOC & LD & $\begin{array}{c}\text { renewable } \\
\text { power }\end{array}$ & $\begin{array}{r}\text { Battery's } \\
\text { switching }\end{array}$ & $\begin{array}{c}\text { dummy load’s } \\
\text { switching }\end{array}$ \\
\hline $0-6$ & $1-9$ & $\begin{array}{l}\mathrm{NA} / \mathrm{NA} / \mathrm{NA} / \\
\mathrm{NA} / \mathrm{NA} / \mathrm{NA} / \\
\mathrm{NA} / \mathrm{NA} / \mathrm{NA}\end{array}$ & $\begin{array}{l}\text { L/NH/ } \\
\text { LN/H/ } \\
\text { L/N/H }\end{array}$ & $\begin{array}{l}\mathrm{NA} / \mathrm{NA} / \mathrm{NA} / \\
\mathrm{NA} / \mathrm{NA} / \mathrm{NA} / \\
\mathrm{NA} / \mathrm{NA} / \mathrm{NA}\end{array}$ & $\begin{array}{l}\text { L/L/L/ } \\
\text { M/M/M } \\
/ H / H / H\end{array}$ & $\begin{array}{c}\text { L/L/L/L/ } \\
\text { L/L/L/L } \\
\mathrm{L}\end{array}$ & $\begin{array}{l}\mathrm{S} 1 / \mathrm{S} 1 / \mathrm{S} 1 / \\
\mathrm{S} 1 / \mathrm{S} 1 / \mathrm{S} 1 / \\
\mathrm{S} 1 / \mathrm{S} 1 / \mathrm{S} 1\end{array}$ & \begin{tabular}{|l|}
$\mathrm{S} 1 / \mathrm{S} 2 / \mathrm{S} 2$ \\
$\mathrm{~S} 1 / \mathrm{S} 2 / \mathrm{S} 2$ \\
$\mathrm{~S} 1 / \mathrm{S} 1 / \mathrm{S} 1$
\end{tabular} & $\begin{array}{l}\text { S1/ S1/ S1/ } \\
\mathrm{S} 1 / \mathrm{S} 1 / \mathrm{S} 1 / \\
\mathrm{S} 1 / \mathrm{S} 2 / \mathrm{S} 2\end{array}$ \\
\hline $6-10$ & 10-18 & $\begin{array}{c}\text { M/M/M/M/ } \\
\text { M/M/M/M } / \\
\text { M }\end{array}$ & $\begin{array}{l}\text { L/MHH } \\
\text { L/M/H/ } \\
\text { L/M/H }\end{array}$ & $\begin{array}{l}\text { NA/NA/NA/ } \\
\text { NA/NA/NA/ } \\
\text { NA/NA/NA }\end{array}$ & $\begin{array}{l}\text { L/L/L/ } \\
\text { M/M/M } \\
\text { /H/H/H }\end{array}$ & $\begin{array}{l}\text { M/M/M/ } \\
\text { M/M/M/ } \\
\text { M/M/M }\end{array}$ & $\begin{array}{l}\mathrm{s} 2 / \mathrm{s} 2 / \mathrm{s} 2 \\
\mathrm{~s} 2 / \mathrm{s} 2 / \mathrm{s} 2 \\
\mathrm{~s} 2 / \mathrm{s} 2 / \mathrm{s} 2\end{array}$ & $\begin{array}{l}\mathrm{s} 2 / \mathrm{s} 2 / \mathrm{s} 2 \\
\mathrm{~s} 2 / \mathrm{s} 2 / \mathrm{s} 2 \\
\mathrm{~s} 1 / \mathrm{s} 1 / \mathrm{S} 1\end{array}$ & $\begin{array}{l}\mathrm{S} 1 / \mathrm{S} 1 / \mathrm{S} 1 / \\
\mathrm{S} 1 / \mathrm{S} 1 / \mathrm{S} 1 / \\
\mathrm{S} 1 / \mathrm{S} / \mathrm{S} 2\end{array}$ \\
\hline $10-15$ & $19-26$ & $\underset{/ \mathrm{H} / \mathrm{H} / \mathrm{H} / \mathrm{H} / \mathrm{H}}{\mathrm{H}}$ & $\begin{array}{l}\mathrm{MH} / \mathrm{L} \\
\mathrm{M} / \mathrm{H} / \mathrm{J} \\
\mathrm{MH}\end{array}$ & $\begin{array}{l}\text { NA/NA/NA/ } \\
\mathrm{NA} / \mathrm{NA} \\
\mathrm{NA} / \mathrm{NA} / \mathrm{NA}\end{array}$ & $\begin{array}{c}\text { LL/M/ } \\
\text { M/M/H/ } \\
\mathrm{H} / \mathrm{H}\end{array}$ & $\begin{array}{c}\mathrm{H} / \mathrm{H} / \mathrm{H} / \\
\mathrm{H} / \mathrm{H} / \mathrm{H} / \\
\mathrm{H} / \mathrm{H}\end{array}$ & $\begin{array}{c}\mathrm{S} 2 / \mathrm{s} 2 / \mathrm{s} 2 \\
\mathrm{~s} 2 / \mathrm{s} 2 / \mathrm{s} 2 \\
\mathrm{~s} 2 / \mathrm{s} 2\end{array}$ & $\begin{array}{c}\mathrm{S} 2 / \mathrm{S} 2 / \mathrm{S} 3 / \\
\mathrm{S} 2 / \mathrm{S} 2 / \mathrm{S} 3 / \\
\mathrm{S} 1 / \mathrm{S} 1\end{array}$ & $\begin{array}{l}\text { S1/ S1/ S1/ } \\
\text { S1/ S1/ S1/ } \\
\text { s2/ S2 }\end{array}$ \\
\hline $15-17$ & $27-43$ & $\begin{array}{c}\text { M/M/M/M/ } \\
\text { M/M/M/M/ } \\
\text { M/M/M/M/ } \\
\text { M/M/M/M/ } \\
\text { M }\end{array}$ & $\begin{array}{l}\text { MH/L/ } \\
\text { MH/L/ } \\
\text { M/H/ } \\
\text { LM/H/ } \\
\text { LM/H/ } \\
\text { LM/H }\end{array}$ & $\begin{array}{c}\mathrm{M} / \mathrm{M} / \mathrm{M} / \mathrm{M} / \mathrm{M} \\
\mathrm{T} / \mathrm{M} / \mathrm{M} / \\
\mathrm{H} / \mathrm{H} / \mathrm{H} / \mathrm{H} / \mathrm{H} / \\
\mathrm{H} / \mathrm{H} / \mathrm{H} / \mathrm{H}\end{array}$ & $\begin{array}{c}\text { L/L/N/ } \\
\mathrm{M} / \mathrm{M} / \mathrm{H} / \\
\mathrm{H} / \mathrm{H} / \\
\mathrm{L} / \mathrm{L} / \\
\mathrm{MN} / \mathrm{M} \\
/ \mathrm{H} / \mathrm{H} / \mathrm{H}\end{array}$ & $\begin{array}{l}\mathrm{H} / \mathrm{H} / \mathrm{H} / \\
\mathrm{H} / \mathrm{H} / \mathrm{H} / \\
\mathrm{H} / \mathrm{H} / \\
\mathrm{H} / \mathrm{H} / \\
\mathrm{H} / \mathrm{H} / \mathrm{H} / \\
\mathrm{H} / \mathrm{H} / \mathrm{H}\end{array}$ & $\begin{array}{c}\mathrm{S} 4 / \mathrm{S} 4 / \mathrm{S} 4 / \\
\mathrm{S} 4 / \mathrm{S} 4 / \mathrm{S} 4 / \\
\mathrm{S} 4 / \mathrm{S} 4 / \mathrm{S} 4 / \\
\mathrm{S} 4 / \mathrm{S} 4 / \mathrm{S} 4 / \\
\mathrm{S} 4 / \mathrm{S} 4 / \mathrm{S} 4 / \\
\mathrm{S} 4 / \mathrm{S} 4\end{array}$ & 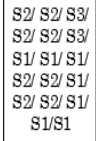 & \begin{tabular}{|c} 
S1/ S1/S1/ \\
S1/ $1 / \mathrm{S} 1 /$ \\
S2/ $22 / \mathrm{S} 1 / \mathrm{S} 1 /$ \\
$\mathrm{S} 1 / \mathrm{S} 1 / \mathrm{S} 1 /$ \\
$\mathrm{S} 1 / \mathrm{S} 1 / \mathrm{S} 2 / \mathrm{S} 2$
\end{tabular} \\
\hline $17-22$ & 44.59 & $\begin{array}{l}\mathrm{NA} / \mathrm{NA} / \mathrm{NA} / \\
\mathrm{NA} / \mathrm{NA} / \\
\mathrm{NA} / \mathrm{NA} / \mathrm{NA} \\
\text { /NA/NA/NA } \\
/ \mathrm{NA} / \mathrm{NA} / \\
\mathrm{NA} / \mathrm{NA} / \mathrm{NA}\end{array}$ & $\begin{array}{l}\text { MHL/ } \\
\text { MH/L/ } \\
\text { MH/ } \\
\text { MHL/ } \\
\text { MHH/ } \\
\text { MHH }\end{array}$ & $\begin{array}{c}\mathrm{M} / \mathrm{M} / \mathrm{M} / \mathrm{M} / \mathrm{M} \\
\mathrm{T} / \mathrm{M} / \mathrm{M} / \\
\mathrm{H} / \mathrm{H} / \mathrm{H} / \mathrm{H} / \mathrm{H} / \\
\mathrm{H} / \mathrm{H} / \mathrm{H}\end{array}$ & $\begin{array}{c}\text { L/L/M } \\
\text { M/M/H/ } \\
\mathrm{H} / \mathrm{H} / \mathrm{L} / \\
\mathrm{L} / \mathrm{M} / \mathrm{M} / \\
\mathrm{M} / \mathrm{H} / \mathrm{H} / \\
\mathrm{H}\end{array}$ & $\begin{array}{c}\mathrm{H} / \mathrm{H} / \mathrm{H} / \\
\mathrm{H} / \mathrm{H} / \mathrm{H} / \\
\mathrm{H} / \mathrm{H} / \\
\mathrm{H} / \mathrm{H} / \mathrm{H} / \\
\mathrm{H} / \mathrm{H} / \mathrm{H} / \\
\mathrm{H} / \mathrm{H}\end{array}$ & \begin{tabular}{|c|}
$\mathrm{S} 3 / \mathrm{S} 3 / \mathrm{S} 3 /$ \\
$\mathrm{S} 3 / \mathrm{S} 3 / \mathrm{S} 3 /$ \\
$\mathrm{S} 3 / \mathrm{S} 3 / \mathrm{S} 3 /$ \\
$\mathrm{S} 3 / \mathrm{S} 3 / \mathrm{S} 3 /$ \\
$\mathrm{S} 3 / \mathrm{S} 3 / \mathrm{S} 3 /$ \\
$\mathrm{S} 3$
\end{tabular} & $\begin{array}{l}\mathrm{S} 2 / \mathrm{S} 2 / \mathrm{S} 3 / \\
\mathrm{s} 2 / \mathrm{S} 2 / \mathrm{S} 3 / \\
\mathrm{S} 1 / \mathrm{S} 1 / \mathrm{S} 2 \\
\mathrm{~s} 2 / \mathrm{S} 3 / \mathrm{S} 2 / \\
\mathrm{s} 2 / \mathrm{S} 3 / \mathrm{S} 1 / \\
\mathrm{s} 1\end{array}$ & $\begin{array}{c}\mathrm{S} 1 / \mathrm{s} 1 / \mathrm{S} 1 / \\
\mathrm{S} 1 / \mathrm{S} 1 / \mathrm{S} 1 / \\
\mathrm{S} 2 / \mathrm{S} 2 / \mathrm{S} 1 / \\
\mathrm{S} 1 / \mathrm{S} 1 / \mathrm{S} 1 / \\
\mathrm{S} 1 / \mathrm{S} 1 / \mathrm{S} 2 / \mathrm{S} 2\end{array}$ \\
\hline $22-24$ & $60-68$ & $\begin{array}{l}\mathrm{NA} / \mathrm{NA} / \mathrm{NA} / \\
\mathrm{NA} / \mathrm{NA} / \mathrm{NA} / \\
\mathrm{NA} / \mathrm{NA} / \mathrm{NA}\end{array}$ & $\begin{array}{l}\text { L/N/H/ } \\
\text { L/N/H/ } \\
\text { L/N/H }\end{array}$ & $\begin{array}{l}\mathrm{NA} / \mathrm{NA} / \mathrm{NA} / \\
\mathrm{NA} / \mathrm{NA} / \mathrm{NA} / \\
\mathrm{NA} / \mathrm{NA} / \mathrm{NA}\end{array}$ & $\begin{array}{l}\text { L/L/L/ } \\
\mathrm{M} / \mathrm{M} / \mathrm{M} \\
/ \mathrm{H} / \mathrm{H} / \mathrm{H}\end{array}$ & $\begin{array}{l}\mathrm{M} / \mathrm{M} / \mathrm{M} / \\
\mathrm{M} / \mathrm{M} / \mathrm{M} / \\
\mathrm{M} / \mathrm{M} / \mathrm{M}\end{array}$ & $\begin{array}{l}\text { S1/ S1/ S1/ } \\
\text { S1/ S1/ S1 } \\
\text { S1/ S1/ S1 }\end{array}$ & \begin{tabular}{|l|}
$\mathrm{S} 1 / \mathrm{S} 2 / \mathrm{S} 2$ \\
$\mathrm{~S} 1 / \mathrm{S} 2 / \mathrm{S} 2 /$ \\
$\mathrm{S} 1 / \mathrm{S} 1 / \mathrm{S} 1$
\end{tabular} & $\begin{array}{l}\mathrm{S} 1 / \mathrm{S} 1 / \mathrm{S} 1 / \\
\mathrm{S} 1 / \mathrm{S} 1 / \mathrm{S} 1 / \\
\mathrm{S} 1 / \mathrm{s} 2 / \mathrm{S} 2\end{array}$ \\
\hline
\end{tabular}

\section{RESULTS AND ANALYSIS}

\subsection{Power Allocation Optimization Summaries}

In the 'Homer software', the solar radiation, wind speed, biomass data, oil consumption, load demand, various types of capital, and replacement cost have been given as input data. After optimizing various input data, $12 \mathrm{~kW}$ solar panels, $10 \mathrm{~kW} 5$ wind power generators, and $10 \mathrm{~kW}$ biomass generators were found shown in Fig. 13. So, the range has been taken from 0 to 12 in the membership function at the solar input, from 0 to 50 in the membership function at the wind generator input, and from 0 to 10 in the membership function at the biomass generator input.

\begin{tabular}{|c|c|c|c|c|c|c|c|c|c|c|c|c|c|}
\hline 하용 & & XIS & $\begin{array}{l}\text { Label } \\
\text { (KW) }\end{array}$ & S6CS25P & $\begin{array}{l}\text { Conv. } \\
\text { KW }\end{array}$ & $\begin{array}{l}\text { Intid } \\
\text { Capptal }\end{array}$ & $\begin{array}{l}\text { Operating } \\
\text { Cost }(S, y) \text { ) }\end{array}$ & $\begin{array}{l}\text { Total } \\
\text { NPC }\end{array}$ & $\mid$\begin{tabular}{c|}
$C O E$ \\
$(5 / \mathrm{kWh}$
\end{tabular} & $\begin{array}{l}\text { Ren. } \\
\text { Frac. }\end{array}$ & \begin{tabular}{|c|} 
Bomass \\
it)
\end{tabular} & $\begin{array}{l}\text { Label } \\
(\mathrm{rss})\end{array}$ & \begin{tabular}{|c} 
Batt. If. \\
(vr)
\end{tabular} \\
\hline & 12 & 5 & 15 & 16 & 15 & 1,750 & 14,777 & $\$ 250,645$ & 0.256 & 1.00 & 134 & 4.805 & 1114 \\
\hline & & 6 & 16 & 16 & 10 & $\$ 55,400$ & 17.119 & 232 & 0.280 & 1.00 & 172 & 258 & 112 \\
\hline & 12 & & 17 & 16 & 14 & & 1766 & 566 & 0.280 & 1.0 & 169 & 5.257 & 10.4 \\
\hline & & & 18 & 16 & 9 & $\$ 39,430$ & 19.906 & $\$ 293.899$ & 0.300 & 1.00 & 215 & 5,624 & 10.5 \\
\hline
\end{tabular}

Fig. 13 - Power allocation optimization summaries

Over-all net current cost is $\$ 250,645$, overall levelized price of energy is $\$ 0.256$ per unit and operating cost is $\$ 14,777$ per year. Levelized price for PV, wind and biogas generator are $0.0532 \$ / \mathrm{kWh}, 0.102 \$ / \mathrm{kWh}$ and $0.256 \$ / \mathrm{kWh}$, respectively.

Table 2 - Energy construction and feeding parameters

\begin{tabular}{|c|c|c|c|c|}
\hline Production & $\mathrm{kWh} / \mathrm{yr}$ & Fraction in \% & Consumption & $\mathrm{kWh} / \mathrm{yr}$ \\
\hline PV & 18.049 & 21 & AC load & 76.636 \\
\hline Wind & 16.370 & 19 & Excess & 3.684 \\
\hline BG & 52.462 & 60 & - & - \\
\hline Total & 86.880 & 100 & Total & 80.320 \\
\hline
\end{tabular}

\section{REFERENCES}

1. P. Moriarty, D. Honnery, Renew. Sustainable Energy Rev. 16 No 1, 244 (2012).

2. Perry Sadorsky, Sustainability 12 No 9, 3867 (2020).

3. Kumar Sunil, Chaudhary, Parvendra Kumar, Rajesh Kumar,
Here, the annual production and use of each renewable energy source are shown in Table 2, where the excess energy is very low.

\subsection{Management Optimization Evaluations}

CASE STUDY - A, FUZZY RULE-9, TIME:00-6

At dark, when PV is unavailable, wind power high, biogas is unavailable, load request low and SOC is high, then load switching of renewable power is wind (S1), battery is OFF (S1) because of battery status high. So, extra energy is sent to dummy load after fulfilling load demand.

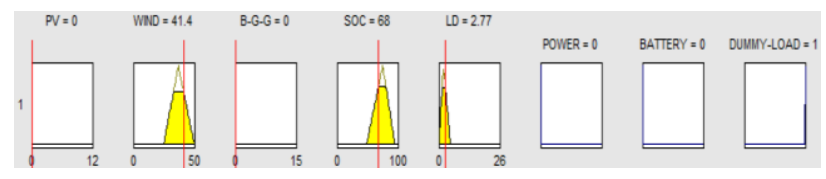

Fig. 14 - When PV-NA, Wind-H, BGG-NA, SOC-H, LD-L, then Power-wind, Battery-Not Charge, Dummy Load-use

CASE STUDY - B, FUZZY RULE-35, TIME:15-17

At daytime, when PV is middle, wind power is low, biogas energy is medium, load request is high, and SOC is low, then load switching of renewable power is $\mathrm{PV}+$ wind + biogas (S4), battery is OFF (S1) because the total energy is required for load demand. Dummy load is OFF.

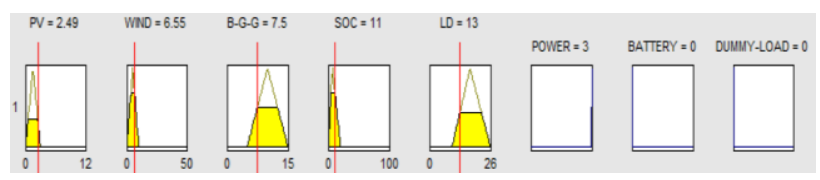

Fig. 15 - When PV-M, Wind-L, BGG-H, SOC-L, LD-H, then Power-PV+wind+BGG, Battery-Not Charge, Dummy Load-NU

\section{CONCLUSIONS}

The proposed system is designed for the Rohingya community where electricity has not yet been reached. The system has much higher efficiency than the conventional method, whereas the energy dissipation is reduced. It has been possible to increase the efficiency of a given system, with the addition of more renewable energy sources and the appropriate fuzzy rule. From the optimizing of renewable energy, it is understood that the price of electricity per unit is $0.256 \$$, which is lighter than the grid. But the overall system is environmentally friendly. The emission of carbon dioxide is $23.2 \mathrm{~kg}$, whereas carbon monoxide is $0.871 \mathrm{~kg}$ per year. They are not higher than non-renewable sources. By observing the cost of the given system, it is clear that the cost of generating electricity from solar energy is comparatively lower than other renewable energy sources. In the meantime, if the whole system is made with solar panels, the cost will fall; and, carbon dioxide emissions can be reduced simultaneously.
International Conference on Technology and Trust (October, 2020).

4. Coilín ÓhAiseadha, Gerré Quinn, Ronan Connolly, Michael Connolly and Willie Soon, Energies 13 No 18, 4839 (2020). 
5. P. Halder, N. Paul, M.U.H. Joardder (Omar), M. Sharker, Renew. Sustainable Energy Rev. 51, 1636 (2015).

6. Amer Al-Hinai, Abdullah Hamed Al-Badi, Eyad A. Feilat, A. Al-Busaidi, International Conference on Energy \& Water Sustainability, November 2012.

7. M. Akhter, S.M.N. Uddin, N. Rafa, S.M. Hridi, Ch. Staddon and W. Powell, Sustainability 12 No 18, 7325 (2020).
8. N. Uddin, S.A. Nahian, S. Islam, J.S. Joy, ICASERT 19256991 (2019).

9. A. Kalmikov, A Handbook for Onshore and Offshore Wind Turbines, 17 (2017)

10. X. Ren, P. Ghassemi, W. Yuan, J. Zhou, P. Chong, $201719^{\text {th }}$ International Conference on Solid-State Sensors, Actuators and Microsystems, 17 (2017).

\title{
Вдосконалений метод нечіткої логіки, заснований на гібридній оптимізації поновлюваних джерел енергії, застосування в реальному часі
}

\author{
Nesar Uddin ${ }^{1}$, Saiful Islam², Yingjun Wu1, Tuton Chandra Mallick³, Mohammad Farhad Hossain¹, \\ Ishaque Mozumder ${ }^{2}, \mathrm{Al} \mathrm{Mamun}{ }^{4}$ \\ ${ }^{1}$ Hohai University, Nanjing, China \\ ${ }^{2}$ Chittagong University of Engineering and Technology (CUET), Chattogram 4349, Bangladesh \\ ${ }^{3}$ Premier University, Chittagong, Bangladesh \\ ${ }^{4}$ University of Bremen, Germany
}

\begin{abstract}
У статті мова йде про оптимальне виробництво та належне управління енергією, яка виробляється з різних поновлюваних джерел енергії та акумуляторних батарей для громади Rohingya (Teknaf, Cox's Bazar, Bangladesh). Виробляючи 210 одиниць електроенергії на добу, люди з кількох сімей можуть задовольнити свої потреби в навантаженні, використовуючи комбінацію сонячної енергії, енергії вітру та біомаси. Спочатку використовувалося програмне забезпечення HOMER для оптимізації кількості відновлюваної енергії та необхідних батарей на основі різних вхідних параметрів для ефективної оптимізації управління енергоспоживанням. Потім застосовувався контролер нечіткої логіки для належної системи оптимізащії управління енергоспоживанням, в якій дане нечітке правило може виконувати нелінійні функції, які використовуються з його власним інтелектом. Нечіткі правила призначені не тільки для роботи в будь-який час доби, але і для використання батарей після задоволення потреби в навантаженні, коли поновлюваних джерел енергії мало. Були отримані оптимальні та контрольовані результати, які дуже ефективні при використанні звичайного методу. Тим часом, нечіткі правила показують, що існує належна корелящія між виробництвом енергії і зарядом-розрядом батареї, фріктивним навантаженням і потребами в навантаженні, що, в свою чергу, знижує зайві втрати енергії.
\end{abstract}

Ключові слова: Гібридна оптимізація відновлюваної енергії, Нечітка система, Оптимізація розподілу енергії, Оптимізація управління енергоспоживанням. 